\title{
Some observations on Zyryan word stress, past and present
}

\section{Introduction}

In Komi and its dialects stress can fall on the first syllable, last syllable or on any other. V. I. Lytkin (1955) has provided a reliable description of the Komi word stress system. Word stress in Komi-Zyryan (henceforth Zyryan) is described as usually having no stable position, although there is a tendency for stress to be initial, even if this is not obligatory (cf. Lytkin 1970: 248). In KomiPermyak the place of stress varies and in the Yazva dialect (Eastern Permyak) some vowels attract stress while others do not (Lytkin 1961: 33-34; 1962: 90, 92-94). Bubrikh (1949), on the other hand, maintains that in Zyryan stress is generally on the first syllable. A more recent description is that of Igushev (1996): as a rule stress falls on the initial syllable, although in some dialects it may alight on $-o v,-o o$ suffixes, on a non-initial syllable in the case of some morphemes or, then again, on suffixes containing the vowels $a$ and $\ddot{o}$.

In what follows I wish to present some comments on the position of stress in the Zyryan word in neutral surroundings, i.e. when it is unaffected by, for example, sentential stress. First thought, I shall briefly consider extant evidence of word stress placement in the past, after which I shall go on to describe some experiments to determine the extent to which stress alights on the initial syllable in Zyryan nowadays and the results. I shall also make brief mention of the possible acoustical composition of the language.

\section{Komi word stress in the past}

While Zyryan word stress is generally on the initial syllable today, the situation in the past has evidently been different. Lytkin has pointed out that the renowned Komi writer M. A. Kuratov even in the 19th century generally marked accent when it did not fall on the initial syllable, which in itself suggests that the position of stress was not then clearly established as being on the first syllable, but this measure also suggests that such non-initially stressed words may have been regularly stressed on the same syllable. If that were the case, then Zyryan word stress would have been at that time typologically different from word stress in Erzya (Estill 2004). A recent collection of some of Kuratov's work (1979) supplies evidence of this practice. Other work by Lytkin (1952) provided even more emphatic evidence of the prevalence of non-initial word stress in 
earlier centuries. Herein Lytkin considered the nature of Old Permian, the predecessor of modern Komi, including grammar and lexicon, on the basis of extant manuscripts from the 17 th and 18 th century. These manuscripts were marked for word stress.

The Old Permian period commenced in the 1300 s, i.e. at the beginning of the historical period, although the evidence in question can probably be most fittingly related to the 17 th century. According to calculations made originally by V. I. Lytkin, and confirmed by my own estimates based on the same historical documentation, word stress patterns have changed in such a way that whereas in the 1600s, of which we have historical evidence, word stress was on the first syllable in the case of approx. 70 per cent of words, it is now on the first syllable in the case of approximately 95 per cent of words (see below). ${ }^{1}$ Table 1 which follows shows the results of calculations made on the basis of an extant manuscript, the Yevgenyevskiye manuscript, which was discovered in the late 18th century and is a Russian transliteration of an Old Permian religious text that was originally written in the Old Permian alphabet. This table provides details concerning the placement of stress on 654 words in the Yevgenevskiye manuscript for which word stress was indicated.

\begin{tabular}{|c|c|c|c|c|}
\hline total words & stress unmarked & monosyllabic words $^{2}$ & stress on $1 \sigma$ & stress on $2+\sigma$ \\
\hline 935 & $281^{3}$ & 26 & 283 & 371 \\
\hline
\end{tabular}

Table 1. Totals for stressed and unstressed words in the Yevgenevskiye manuscripts.

The problem faced in interpreting these figures concerns the number of words that were not marked for stress. These do not seem to have anything in common, or anything that would single them out from the other words in the text. Furthermore, there were not very many monosyllabic words in the text. We must, then, rely on conjecture. If we assume that unstressed words were omitted because initial syllable stress may have been anticipated as a natural first choice, then calculations of word stress occurrence in the manuscripts become heavily weighted in favour of initial syllable word stress, and calculations of word stress on subsequent syllables is minimised. The resulting estimations are therefore very conservative. The figure below shows how the evidence so far

\footnotetext{
${ }^{1}$ It will be observed that no separation of word and sentential stress has been made in determining the figure for the present day, whereas allowances were made for sentential stress in the historical data.

${ }^{2}$ This is a fairly rough estimate, because of my difficulty in separating the words in the text.

${ }^{3}$ The number includes monosyllabic words.
} 
can be interpreted on a chart. The curve shows at the very least the changes in word stress that have taken place over the last four hundred years. According to this conservative calculation, at least every third word would have been stressed on a syllable other than the first. This situation is visually shown in figure 1 .

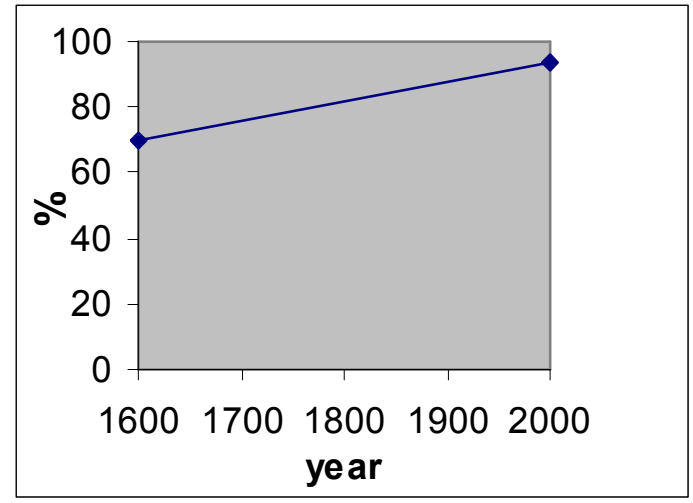

Figure 1. Chart with curve showing a conservative estimate of the possible historical development of word stress on first syllable in Komi as percentage ( $y$-axis) for the years 1600 to 2000 (x-axis). ${ }^{4}$

\section{Zyryan word stress today}

While word stress in Permyak and the Yazva dialect shows certain variation despite the prevalence of initial stress, which can well be understood in the light of the previous section, in the predominant ${ }^{5}$ Komi language, Zyryan, as mentioned above, word stress is generally regarded as being on the first syllable. In order to determine to what extent this is in fact the case today, I carried out an experiment.

\section{I. Description of first auditory experiment}

To discover the extent to which word stress is placed on the first syllable in

\footnotetext{
${ }^{4}$ The Komi figure has been derived according to my own calculations based on the photographs of extant manuscripts of the Yevgenyevskiye manuscripts published in V.I. Lytkin (1952: Appendix 2). My own original calculation for non-initial syllable stress was $\geq 39 \%$, but after tempering this with Lytkin's warning of the presence of sentential stress (I allowed $10 \%$ for this) and his observation that $80 \%$ of stress was radical and $20 \%$ (for which I made a further allowance of 20 $\%$ which meant that one third would have been radical) suffixal, although no mention was made of the syllable on which radical stress had been placed, I felt that by adding $31 \%$ and rounding the final figure to $70 \%$ for initial stress that I would not be accused of exaggerating the prevalence of non-initial word stress in Komi in the 1600s.

${ }^{5}$ There are about twice as many Zyryan speakers as there are Permyaks.
} 
Zyryan, I asked a native speaker (SA) to read portions from recently published Zyryan fiction, at least for the purposes of auditory experiments. My informant is from the village of Kuratovo in the Syktyv raion and the recordings were made when she was 25. She spoke the Middle Sysola dialect. I understand that my informant's pronunciation was quite representative of the Zyryan dialects in general. The reading material was an extract from a story in the book Ėžva pedymsa zonka by V. Timin describing the adventures of a young boy, and the text was standard. One reason for choosing the text, in addition to its general popularity (I have heard about this from other Zyryans), was the fact that it included very few words that have entered Zyryan from or through Russian. Those few words that did occur were eliminated from the analysis. ${ }^{6}$ The recording took place at the Department of Finno-Ugrian Studies of the University of Helsinki in conditions conducive to the production of reasonably good sound quality, at least for the purposes of the experiment.

The auditory experiment was accompanied by a somewhat modest acoustic experiment assisted by the same informant, SA. In this case nine short sentences were analysed in order to discover factors which may indicate the extent to which fundamental frequency, intensity and duration were involved in the production of word stress. This was carried out by measuring the acoustic parameters of these correlates.

\subsection{Description of second auditory experiment}

It may not be convincing to claim that the evidence of one speaker is representative of all, at least as far as auditory experiments are concerned. A further auditory experiment was therefore conducted to compare the word stress pattern of several speakers. Three of the informants who assisted with this experiment spoke the Upper Vychegda dialect (CL), (OM) and (OO), and one the Syktyvkar dialect (IG). Each informant read 274 words onto a CD disk using a Plextalk recorder. The extract used was chosen at random from the above-mentioned Ėžva pedymsa zonka by V. Timin.

\subsection{Results}

\subsection{Placement of word stress in first auditory experiment}

Although SA read several pages of text, for my own analysis it was sufficient to consider only the first 651 words, since the general pattern of initial syllable

\footnotetext{
${ }^{6}$ It is not exactly clear, however, what a "loan" word is and how it should be defined, i.e. how much the form should still resemble that of the language from which it has been derived. For safety's sake recent introductions from Russian (mostly since the October Revolution) were left out.
} 
stress was so predominant. In fact, of those words, only in the case of 35 did stress switch to a syllable other than the first. This meant that 94.6 per cent of words were stressed on the first syllable, and when sentential stress, for which no allowance was made, is taken into consideration it can safely be said that in Zyryan today word stress falls with regularity on the initial syllable, as the literature has given us to understand. Confirmation of the perceived placement of stress was made by two speakers of languages other than Komi, i.e. English and Finnish, and the experiments were conducted in 2003. This does not, however, mean by definition that were word stress to fall on a syllable other than the first in a neutral environment, that such a pronunciation would be unacceptable, as it would be in e.g. Finnish.

Why did 35 words not receive initial stress? When examined more closely the 35 words on which stress does not fall on the first syllable seem to have been influenced by what was on their right. This can be shown by comparing them to those words that are initially stressed. Table 2 makes that comparison.

\begin{tabular}{|l|l|l|l|}
\hline & word total & juncture to right & $\%$ \\
\hline $1 \sigma$ stress & 616 & 156 & 25.3 \\
\hline $2 \sigma \& 2 \sigma+$ stress & 35 & 14 & 40.0 \\
\hline
\end{tabular}

Table 2. Total number of words with stress on initial and subsequent syllable in text read by SA. Table also shows the number and percentage of words with juncture to immediate right for words stressed on either the initial or subsequent syllable.

The above table shows that in the case of Zyryan speaker SA initial word stress was more general when the word was not followed immediately by a point of juncture to its right $^{7}$ (only $25.3 \%$ deviations from initial stress). On the other hand, if a word was immediately followed by a point of juncture, the chances of stress occurring on a syllable other than the first were to a certain extent greater (40.0\% deviations from initial stress). Those words with juncture on their immediate right were thus more prone to shift stress onto a syllable other than the first. In the order in which the words occurred in the text the types of juncture involved were the following and in the following order:

fs cm fs da fs fs cm fs cm ex cm fs fs cl (.,.-..,.,!,...)

$$
\begin{aligned}
& (\mathrm{fs}=\text { full-stop [.] }, \mathrm{cm}=\text { comma [,] } \mathrm{cl}=\text { colon }[:], \text { ex }=\text { exclamation mark [!], } \\
& \mathrm{da}=\text { dash [-] })
\end{aligned}
$$

\footnotetext{
7 'Right' here refers of course to the position on the page from which my informant read. In normal speech this would mean the juncture that occurs after the feature under investigation.
} 
While it would seem possible to suggest that juncture affects the placement of word stress, care must be taken in the interpreting the data, since in the text only 35 examples were discovered for analysis. The possibility that sentential stress may have influenced the placement of word stress was also taken into account. In fact, 22 of the 35 carried sentential stress. From the forgoing it would seem that, as might be expected, sentential stress accounts for the majority of deviations from initial syllable stress in Zyryan.

\subsubsection{Placement of word stress in second auditory experiment}

For the second auditory experiment four female informants were asked to read a page from a current children's book, each informant reading all 274 words onto a CD. The results of the analysis are shown in the table below.

\begin{tabular}{|l|l|l|l|l|l|}
\hline & LC & IG & OM & OO & total \\
\hline words read & 274 & 274 & 274 & 274 & 1096 \\
\hline word stress non-initial & 5 & 8 & 10 & 3 & 26 \\
\hline \% word stress non-initial & 1.8 & 2.9 & 3.6 & 1.1 & 2.4 \\
\hline
\end{tabular}

Table 3. Incidence of word stress placement, percentages and totals for four Zyryan speakers.

Compared with SA's 94.6 per cent initial syllable word stress, on average the four Zyryan informants examined above stressed the first syllable in 97.6 per cent of cases. Since sentential stress has not been taken into consideration, on the basis of this further evidence it would be reasonable to conclude that in Zyryan word stress falls regularly on the first syllable, although it must still be borne in mind that this does not per se mean that non-initial word stress is unacceptable in the judgment of the native speaker. This problem requires separate investigation, and is not the concern of the present paper. The conclusion to be drawn is that word stress is on the initial syllable in Zyryan. As far as deviations from this pattern are concerned, these are probably influenced by juncture and of course sentential stress, as stated in section 3.3.1.

\subsubsection{The need for acoustic experiments}

It would seem that little experimental research has been carried out into the acoustical nature of Zyryan. ${ }^{8}$ Although not always regarded as the main factor

\footnotetext{
${ }^{8}$ Some comparative research concerning Finnish and Zyryan vowels has been carried out (Savela 1999).
} 
in many studies, it has been observed in, for example, Erzya (Estill 2004) and Greek (Botinis 1998) that word stress may have more to do with intensity (measured in amplitude) than with fundamental frequency $\left(\mathrm{F}_{0}\right)$, measured in Hertz, although the measurement of intensity is fraught with complications (Iivonen 2004). Further, the role of duration must always be considered. The influence of Russian must also been taken into consideration. According to Natalia Svetozarova (1998: 264), in Russian "stressed vowels as a rule, exhibit higher values of these parameters (length and intensity) than unstressed ones". I carried out a small preliminary investigation of nine simple Zyryan sentences read by SA and taken from an introduction to Komi (Kokkonen 1984: 18-19), with the object of finding clues concerning the most relevant acoustic features or combination of correlates likely to occur in Zyryan word stress, as an indicator for future research. These sentences, which include two questions, are shown below.

(1) Керка лэптанінын уджала. ${ }^{10}$

Udžala kerka *leptaninyn. ${ }^{11}$

'I work on the buildings.'

(2) Локтан гожӧм пенсия вылӧ петӧ.

Loktan gožöm ṕenśija vylö *ṕetö.

'S/he gets her/his pension next year.'

(3) Кьттиӧ мунанныл отпускӧ?

* Kytćö munannyd otpuskö?

'Where are you going on your holidays?'

(4) Кыззи кӧсъянныд коллявны отпускнытӧ?

Kydźi kösjannyd kol'l'avny *otpusknytö?

'How will you spend your holidays?'

(5) Мунамӧй саридз дорӧ.

Munamöj saŕid'z *dorö.

'Let's go to the seaside.'

(6) Талун вывті тӧла

Talun vyvti *töla.

'It's very windy today.'

\footnotetext{
${ }^{9}$ These sentences were analysed at the Department of Speech Sciences at the University of Helsinki using the SoundScope and SoundEdit programs.

${ }^{10}$ In this instance my informant "corrected" the word order.

$11 *=$ sentential stress.
} 
(7) Уна сикас пывсян эм.

Una síkas *pyvśan em.

'There are many kinds of sauna.'

(8) Пьвсьӧм бӧрын мортлӧн горшыс косьмӧ.

Pyvśöm *böryn mortlön *goršys kośmö.

'You feel thirsty after a sauna.'

(9) Медбур шойччӧмыс ветлӧдлӧм.

Medbur *šojććömys vetlödlöm.

'Exercising is the best way to rest.'

\begin{tabular}{|c|c|c|c|}
\hline syllable & sent. ref. & parameters & occur. \\
\hline \multirow[t]{2}{*}{$m u, s i, p y v$} & $5,7,8$ & none & 3 \\
\hline & & $\mathrm{F}_{0}$ & 0 \\
\hline lok, vet & 2,9 & $\mathrm{~F}_{0}+$ int & 2 \\
\hline ṕen, $m u, s a$ & $2,3,5$ & $\mathrm{~F}_{0}+$ dur & 3 \\
\hline ker, go, mort, koś & $1,2,8,8$ & $\mathrm{~F}_{0}+\mathrm{int}+\mathrm{dur}$ & 4 \\
\hline$k y d^{\prime}, k o l^{\prime}$ & 4,4 & int & 2 \\
\hline$v y, o t, k o ̈ s, t a, v y v, u$, med & $2,3,4,6,6,7,9$ & int + dur & 7 \\
\hline \multirow[t]{2}{*}{$u d$} & 1 & dur & 1 \\
\hline & & total & 22 \\
\hline
\end{tabular}

Table 4. 1st column shows syllables from Zyryan sentences above. 2nd column shows reference letter for sentences from which the syllable was taken. 3rd column shows which parameters were most prominent acoustically. 4th column shows number of syllables in which a parameter or combination of parameters was prominent.

Measurements were made of $F_{0}$ (hertz) and intensity (volts), and durations of vowel nuclei were also recorded. Table 4 summarises the results. I have not included the data, the criteria determining the limits for the inclusion of prominent features, etc, since the purpose of the experiment is simply to lay a foundation for future analyses.

In order not to prejudice the results those syllables which were either not stressed or were subject to sentential stress were left out, leaving only wordstressed syllables. The modest experiment above thus provided a starting point for investigating which features may be most likely to produce word stress in 
Zyryan, but the material is insufficient for drawing any conclusions. Of interest, however, is the fact that in 14 cases out of $22(64 \%)$ duration is a factor contributing to word stress. I have already embarked on the task of seeking to determine the most relevant factors contributing to word stress, and while the results are as yet incomplete it would seem that duration is the most important parameter, although it may be that longer duration is very often accompanied by greater fundamental frequency.

As far as the acoustical nature of Zyryan is concerned, the matter has not yet been sufficiently investigated. The modest inquiry of mine would suggest that the part played by duration is considerable, and that fundamental frequency in the production of word stress approaches that generally assumed for other languages. This question as well as others concerning Zyryan prosody is therefore left open for further research and discussion.

\section{Conclusion}

In the light of the evidence presented in the previous section, and assuming the typicality of my informant, it can be stated that, since word stress occurs on the initial syllable in 94.6 per cent of cases for one typical speaker and in 97.6 per cent of cases for four other speakers, not taking into consideration the affect of sentential stress, in Zyryan word stress occurs regularly on the first syllable. As shown in figure 1 in section 2 , stress has gradually moved onto the first syllable after being historically much less regular. Word stress in the Mordvin languages has passed through similar stages of change, resulting in preference-based stress in modern Erzya (Estill 2004). As V. I. Lytkin has pointed out (Lytkin 1970: 248), initial-syllable word stress in Zyryan is not obligatory. Lytkin provides examples. However, despite such examples Zyryan may be reaching or have already reached a stage in which it is difficult to sustain this assertion, since from the material described in section 3 it would indeed be difficult to find examples of non-initial word stress for which another explanation could not be found, such as sentential stress, juncture, contrastive stress, etc., and after all it is about thirty-five years since Lytkin wrote down his observations. Zyryan may be passing or have already passed over a "boundary" between what can be regarded as normal first-syllable word stress and predominantly first-syllable word stress mixed with preference-based stress, the latter being the pattern at least for so many centuries. Much depends on the attitude of speakers to digressions from initial syllable word stress.

As far as the acoustical nature of Zyryan is concerned, the matter has not yet been sufficiently investigated. The modest inquiry of mine would suggest that the part played by duration is considerable, and that fundamental frequency in the production of word stress approaches that generally assumed for other 
languages. This question as well as others concerning Zyryan prosody is therefore left open for further research and discussion.

\section{References}

Botinis, Antonis 1998: Intonation in Greek. - Daniel Hirst \& Albert Di Cristo (ed.), Intonation systems. A survey of twenty languages. Cambridge: Cambridge University Press. 288-310.

Bubrikh = Bubrih, D. V. 1949: Grammatika literaturnogo komi jazyka. Leningrad: Leningradskogo gosudarstvennogo universiteta im. A. A. Ždanova.

Estill, Dennis 1995: The realization of word stress on Russian loan-words assimilating into Erzya-Mordvin. Unpublished master's thesis. University of Helsinki.

Estill, Dennis 2004: Diachronic change in Erzya word stress. Mémoires de la Société Finno-Ougrienne 246. Helsinki: Suomalais-Ugrilainen Seura.

Igushev = Igušev, E. A. 1996: Očebnöi posobie. Syktyvkar.

Iivonen, Antti 2004: Puoliunohduksiin jäänyt puheen intensiteetti. - Tapio Seppänen, Kari Suomi \& Juhani Toivanen (ed.), Fonetiikan päivät 2004. Oulu: MediaTeam Oulu \& Suomen kielen, informaatiotutkimuksen ja logopedian laitos, Oulun yliopisto. 48-51.

Kokkonen, Paula (ed.) 1984: Komisyrjäänin kielioppia ja tekstejä. Hilfsmittel für das Studium der finnisch-ugrischen Sprachen IX. Helsinki: Suomalais-Ugrilainen Seura.

Kuratov, Ivan 1979: Moja Muza. Sobranie hudožestvennyh proizvedenij. Syktyvkar: Komi knižnoe izdatel'stvo.

Lytkin, V. I. 1952: Drevnepermskij jazyk. Čtenie tekstov, grammatika, slovar'. Moskva: Izdatel'stvo Akademii Nauk SSSR.

Lytkin, V. I. 1955: Sovremennyj komi jazyk, fonetika, leksika, morfologija. Syktyvkar: Komi knižnoe izdatel'stvo.

Lytkin, V. I. 1961: Komi-jaz'vinskij dialekt. Moskva: Izdatel'stvo Akademii Nauk SSSR.

Lytkin, V. I. 1970: Problema leksičeskogo udarenija v finno-ugorskih jazykah. - Acta Linguistica Academiae Scientiarum Hungaricae 20 (3-4): 245-263.

Lytkin, V. I. (ed.) 1962: Komi-permjackij jazyk. Kudymkar: Komi knižnoe izdatelstvo.

Savela, Janne 1999: Tutkimus komisyrjäänin ja suomen vokaalifoneemien rakenteesta. (With English summary.) - Sananjalka 41: 167-176.

Svetorazova, Natalia 1998: Intonation in Russian. - Daniel Hirst \& Albert Di Cristo (ed.), Intonation systems. A survey of twenty languages. Cambridge: Cambridge University Press. 261-274.

Timin, V. 2000: Ěžva pedymsa zonka. Syktyvkar: Èsköm Izdatel'stvo.

Dennis Estill<estill@mappi.helsinki.fi>

Väinöläntie 20

FI-12310 Ryttylä 